of a figure on an unpublished plate, prepared by Hector, in a series labelled "Pakawau" in his handwriting.

The cause of the error may lie in the numbering of the specimens; specimens from Pakawau are registered with the New Zealand Geological Survey locality number 409 (collected by the Geological Survey in 1866), and those from Waikato Heads bear the number 410 (collected by the Geological Survey in 1868). Apparently, a slab from the Pakawau collection was wrongly numbered and placed in the Waikato Heads collection.

The earliest New Zealand angiosperms known at present are those from beds in the Middle Clarence Valley, which on the evidence of plant microfossils are Turonian in age.

New Zealand Geological Survey,

$$
\text { D. R. McQueen }
$$

156 The Terrace,

Wellington, New Zealand. Sept. 22.

${ }^{1}$ Arber, E. A. N., N.Z. Geol. Surv. Pal. Bull., 6, 62 (1917). 2 Edwards, W. N., Ann. Mag. Nat. Hist., (10), 13, 86, 87 (1934), ${ }^{3}$ Ettingshausen, C. v., Trans. N.Z. Inst., 23, 237 et seq. (1891).

${ }^{4}$ Hector, J., Det. Cat. Ind. Col. Exhib. (London), Fig. 24A, 3, N.Z. Geol. Survey, Wellington (1886).

\section{A Seed-borne Nematode Infestation in Annual Asters}

Aphelenchoides ritzema-bosi has a wide host-range but is most frequently recorded as a pest of chrysanthemums. In this plant, infestations usually start at the base of the stem and work upwards in the direction of the flower head. In severe attacks, most of the leaf area is killed, and the flower head itself may become infested. Chrysanthemums are normally propagated vegetatively, and hence seed-borne infestation is unlikely to occur. However, some hosts of $A$. ritzema-bosi are grown from seed, and the object of this communication is to record seed-borne infestation in the annual aster (Callistephus chinensis).

In early May 1954, severe injury was noted on aster plants being grown in sterilized compost in seed boxes on a nursery in Suffolk. These plants were found to be heavily infested with $A$. ritzemabosi, living mainly ectoparasitically in the leaf axils. Fortunately a supply of the original seed was available for examination. $14 \mathrm{gm}$. of seed was placed in a Baermann funnel and more than three hundred nematodes were extracted. Small pieces of leaf and sepal debris were present mixed with the seed, and nematodes emerged in large numbers from this debris and also from seed from which the debris had been removed. It therefore seems probable that the species was living both ecto- and endo-parasitically in the flower head, and that a proportion of the nematodes was attached to or in close association with the seed coat. Identical symptoms were reproduced in the laboratory on aster plants raised from this seed in sterilized compost.

Seed-borne infestation in the genus Aphelenchoides has not hitherto been recorded. A full account of this occurrence and of the symptoms on the aster plants will be published elsewhere.

National Agricultural Advisory Service,

E. B. BRown Anstey Hall

Trumpington, Cambridge.

Oct. 7.

\section{The Genetic Component of Language}

R. W. Thompson, in discussing the genetic component of language ${ }^{1}$, complains that Darlington and Mather, in an introduction to geneties", "have simplified the issue". This is true, and one of the complications $\mathrm{Mr}$. Thompson introduces is highly appropriate. But in my original paper I had considered it ${ }^{3}$.

In this paper I tried to explain certain principles.

(1) That the three threads by which continuity and change may be followed in language, namely, grammar, etymology and phonetics, are in a long-term sense independent.

(2) That only on the phonetic side do we expect or find a serious genetic component.

(3) That the genetic preference of the group rather than the genetic capacity of the individual is what determines phonetic evolution.

Among the instances I gave of the working of these principles was the one quoted by Mr. Thompson, namely, the intrusion of the dental fricative along different lines, at different times and in different parts of the Spanish-speaking world, an instance which might be elaborated from the study of Latin American dialects.

Mr. Thompson suggests that the theory of a genetic component of language was regarded as speculative by Darlington and Mather. It is speculative in the sense that it is a beginning rather than an end of investigation. It opens new ground for research in phonetics, linguistics, anatomy and psychology, and ultimately in the general understanding of human society. What we have to do is to apply non-genetic ideas and techniques in relation to the genetics of individuals and of populations.

I may give an example of each.

(1) Mr. Thompson agrees that "the speech organs of various races vary in shape". But he maintains that these variations could have no influence on the production of speech except on timbre. Are we to suppose, then, that the defects of speech which may distinguish one child from his brothers and sisters never have any basis in the shapes of nerves, muscles or bones? Or conversely, that the established genetic control of differences in tongue control has no effect on the ease of pronouncing various sounds? I do not believe either of these corollaries of Mr. Thompson's view. But the anatomist and the speech therapist could test their truth, and their observations would help to solve our problem.

(2) We have to discover just how the community, its classes and individuals, interact over long spaces of time in small and large, stable and changing, literate and illiterate societies. We now understand enough of the genetics of these situations to relate them with the historical evidence 4 .

Such is the speculation. But the principle of genetic determination in language itself is far from speculative. Those who now object will be telling us soon enough that it is little more than a truism.

Botany Department, C. D. Darlington Oxford.

Dec. 16.

1 Thompson, R. W., Nature, 174, 1095 (1954).

2 Darlington, C. D., and Mather, K., "The Elements of Genetics" (Allen and Unwin, London, 1949).

${ }^{3}$ Darlington, C. D., Heredity, 1, 269 (1947).

- Darlington, C. D., "The Facts of Life" (Allen and Unwin, London, 1953). 